ties, pose a special threat to the general public.-I am, etc.,

R. G. HENDRICKSE

Liverpool School of Tropical Medicine

Liverpool

\section{Sarcoma after Intramuscular Iron Injection}

SIR-I read with interest the latest instalment from Messrs. A. E. Mackinnon and J. Banceweicz in the long story of intramuscular iron therapy and human cancer ( 5 May, p. 227). As the authors themselves suggest, the occurrence of the malignant tumours at the site of earlier injections of iron dextran may be entirely fortuitous. I entirely agree with this view and it is a pity that no data were given that might lend support to it. For example, one would like to have some idea of the number of people who have been treated with repeated intramuscular iron dextran and have not developed tumours. Those treated, say, 15 years ago would provide valuable data in this respect. One would also like to know the incidence of sarcoma (or lack of it) at the site of intramuscular injection of other types of pharmaceutical preparations (such as insulin and penicillin). Admittedly, this information is not readily available, but one would anticipate that hospital records would provide valuable information of this sort.

Turning to the animal data, I feel that the authors did not emphasize sufficiently the importance of "iron overload" in the production of local sarcoma by iron dextran injections in rats and mice. The exhaustive studies of Golberg and his colleagues ${ }^{1-3}$ leave little room for doubt that tumours developed only in those animals treated repeatedly with high doses (of the order of $0.5 \mathrm{ml}$ in the rat and $0.2 \mathrm{ml}$ in the mouse). Lower doses, which were insufficient to produce an "iron overload," did not produce tumours. This is an important consideration since the doses to the human are unlikely to cause an "iron overload." In addition, it is felt that insufficient attention has been given to the "inon-laden" macrophages that have been reported ${ }^{5-7}$ by a number of workers in the sarcomas produced by iron dextran in rats and mice. In my view, their absence from the human tumours studied by Messrs. Mackinnon and Bancewicz merited some comment.

With regard to the "distant" as opposed to local tumours reported by Langvad, ${ }^{8}$ I would point out that these were reported only in mice. In an earlier publication from this institute $^{9}$ the reasons for interpreting with caution the results of carcinogenicity tests in mice have been discussed at length, so that in my view there is no valid evidence that iron dextran induced tumours at sites other than the injection site in rodents.

I do feel that in any report of cases of sarcomas arising at the sites of injection of iron dextran-or other pharmaceutical preparations-it would be more helpful if sufficient background data could be provided to enable readers to place such reports in their proper perspective.-I am, etc.,

Paul Grasso

British Industrial Biological Research Association Carshalton, Surrey

1 Golberg, L., Martin, L. E., and Smith, J. P., Toxicology and Applied Pharmacology, 1960, 2, 2 Golberg, L., Smith, J. P., and Baker, S. B.
3 Baker, S. B., de C., Golberg, L., Martin, L. E., and Simith, J. P., fournal of Pathology and

Bacteriology, 1961, 82, 453.
ritish Medical foumal, 1960, 1, 788; ibid, 1961 , $1,114$. 5 Haddow, A., and Horning, E. S., Fournal of the

Roe, F. J. C. Haddow, A., Dukes, C. E., and 1964, 18, 801. C. V., British Fournal of Cancer,

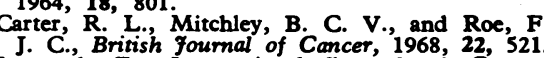
J. C., British fournal of Cancer, 1968, 22, 521 Langvad, E.', Grasso, P., and Crampton, R. F., Food and
Cosmetics Toxicology, 1972, 10, 418.

\section{Neurological Disease Associated with Folate Deficiency}

SIR,-Dr. E. H. Reynolds and his colleagues (19 May, p. 398) cautiously suggest a causative role for folic acid in the development of organic brain syndromes.

It seems to me that it is more likely that the organic dementia is the cause of the deficiency. Certainly in the elderly folic acid anaemia is not uncommon and certainly I have been of the opinion that in many cases an underlying dementia has led to the dietetic deficiency rather than the converse.-I am, etc.,

Sifnal, Salop

P. W. HuTtoN

\section{Mediterranean Anaemia in Antiquity}

Sir,-Dr. W. T. Menke (26 May, p. 489) has convincingly demonstrated that the manifestations of sickle-cell-thalassaemia were observed by the writers of the Hippocratic corpus. It is possible to infer that the Greeks before this time had also recognized the ill effects due to the absence of glucose6-phosphate dehydrogenase, which is common among the peoples of the Mediterranean, conferring with it a protection against falciparum malaria. Those with this enzyme deficiency may develop acute haemolytic episodes if they eat the broad bean (Vicic $f a b a)$ and this syndrome is termed favism as a result.

Pythagoras is best remembered today for the theorem which bears his name, but among the peoples of antiquity he was renowned as a mystic who founded a religion based chiefly on the tenets of the transmigration of souls and the sinfulness of eating the broad bean. ${ }^{1}$ It may be that this apparently eccentric prohibition was based on observing the untoward effects which followed in some of those who ate the bean and that, like some of the other dietary restrictions which are incorporated into religious practices, it has a sound empirical basis.-I am, etc.,

\section{Birmingham}

H. A. WALDRON 1 Russell, B., History of Western Philosophy, 2nd
edn., p. 50. London, Allen and Unwin, 1965.

\section{Rabies}

SIR,-Dr. A. D. Macrae's review (10 March, p. 604) of this topic makes interesting reading.

Experience in the British Isles may make it appear that rabies is "beaten." In contrast, in a Nigerian rural practice, which is not as rich in population as in variety, in four and a half years (July 1968-December 1972) I have seen eight cases of classical rabies and five other cases of encephalitis of uncertain type which in retrospect were diagnosed as "most probably rabies." All these patients died, and all within 48 hours of being seen.

Quarantine practices and the control of wild life are not easy in vast continents like Asia, Africa, or America. Treatment of rabies does not yet produce cure. I therefore plead for more effort by researchers in the direction of better and cheaper prophylaxis in the meantime, while working towards a real cure for this very real hazard to man.-I am, etc.,

Ikedife Hospital

DOZIE IKEDIFE Nnewi, Nigeria.

\section{Purpura Associated with Vomiting}

SIR,-I was interested in the observations of Dr. M. F. Burke and Dr. Janet M. Marks (26 May, p. 488) on a case of purpura of the head and neck associated with vomiting in pregnancy.

They comment that purpura of this area has been described in association with vomiting, quoting a 1972 source. I am sunprised this description in the literature is so recent, for I have often observed purpura of the head and neck following vomiting. I believe the first time I noticed the association was in one of my own children when she was three years old, in 1962. The most recent occasion was the day before I read your correspondent's letter. I was on this occasion invited to see a young woman who had an attack of diarrhoea and vomiting. Her mother pointed out to me that the girl had a rash, thinking it might be some exanthem. Examination revealed it to be a purpuric rash of the head and neck only. Neither drug nor pregnancy was involved, and I assume that the aetiology of the rash is a sudden rise in the venous and capillary pressure in the head and neck caused by a rise in intrathoracic pressure during vomiting.

I have, however, never seen such a rash with eczematous features, as described by your correspondents.-I am, etc.,

Dartford, Kent

P. W. Pitr

\section{Work Fit for a Consultant}

SIR,-Before this correspondence is closed, may I point out that according to $\mathrm{Mr}$. J. P. Turney (2 June, p. 555) his proposed "specialist" (or permanent subconsultant) will do more or less the same routine work and have the same responsibilities as a consultant. For this he will, quite reasonably, get the same pay. But, in addition, he will have a contractual obligation for emergencies and, when junior staff are scarce, will be the first to forgo their assistance. If, as well as all that, this busy, middle-aged specialist is not allowed to do private practice or to be considered for a merit award, he really will be exploited by the consultants "with whom" (sic) he works.

Of course, if he can do private practice and can get a merit award, it will be difficult to distinguish him from a real consultant; though with his title, no doubt the private patients and the Advisory Committee on Distinction Awards can be relied upon to keep him in his proper station.-I am, etc.,

Middlesbrough 